\title{
Influence of stone cutting waste and ground waste clay brick on the hydration and packing density of cement pastes
}

\section{Influência de resíduos de corte de rochas e de blocos cerâmicos moídos na hidratação e no empacotamento de pastas cimentícias}
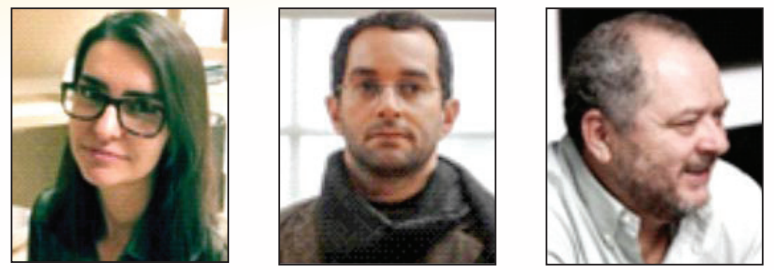

C. A. A. ROCHA camilaabelha@coc.ufrj.br

G. C. CORDEIRO ${ }^{b}$ gcc@uenf.br

R. D. TOLEDO FILHO a toledo@coc.ufrj.br

\section{Abstract}

The present work aims to study the replacement of Portland cement (PC) by stone cutting waste (SW) and ground waste clay brick (BW) in binary and ternary pastes. Thermogravimetry and differential thermal analysis tests were carried out at various ages in order to investigate the development of the cement hydration reactions in the presence of those wastes. The packing density was calculated in accordance with the Compressible Packing Model to understand the physical effect of those wastes. Compressive strength tests were also performed and the results were related to hydration and packing. Considering the substitution levels studied, the results indicated that the use of SW in the binary mixture accelerated the hydration reactions, and the particles packing density and compressive strength were maintained. The use of BW in the binary mixture caused a small acceleration in the hydration reactions and there was an indication of pozzolanic activity, although the compressive strength was reduced in comparison with the reference paste. In the ternary mixture, the combined effect of both wastes resulted in the maintenance of compressive strength for cement replacement content of $30 \%$.

Keywords: stone cutting waste, ground waste clay brick, cementitious pastes, thermal analysis, packing density, compressive strength.

\section{Resumo}

O presente trabalho teve por objetivo estudar a substituição do cimento Portland (CP) por resíduos de corte de rochas (RCR) e de blocos cerâmicos moídos (RBC) em pastas binárias e ternárias. Ensaios de termogravimetria e de análise térmica diferencial foram realizados em várias idades com a finalidade de investigar a evolução das reações de hidratação de cimento em presença dos resíduos. Para compreender o efeito físico dos resíduos foi calculada a densidade de empacotamento de acordo com o Modelo de Empacotamento Compressível. Ensaios de resistência à compressão também foram realizados e os resultados foram relacionados com a hidratação e o empacotamento. Considerando os níveis de substituição estudados, os resultados indicaram que a utilização do RCR na mistura binária acelerou as reações de hidratação, e a densidade empacotamento das partículas e a resistência à compressão foram mantidas. A utilização do RBC na mistura binária provocou uma pequena aceleração nas reações de hidratação e houve indícios de atividade pozolânica, embora a resistência à compressão tenha reduzido em comparação com a referência. Na mistura ternária, o efeito conjunto de ambos os resíduos acarretou a manutenção da resistência à compressão para um teor de substituição de cimento de $30 \%$.

Palavras-chave: resíduo de corte de rochas, resíduo de blocos cerâmicos, pastas cimentícias, análise térmica, densidade de empacotamento, resistência à compressão.

Institute Alberto Luiz Coimbra of Graduate and Engineering Research - COPPE, Universidade Federal do Rio de Janeiro, Rio de Janeiro, RJ, Brasil 21941-972

Center for Science and Technology, Universidade Estadual do Norte Fluminense Darcy Ribeiro, Campos dos Goytacazes, RJ, Brasil 28013-602 


\section{Introduction}

The Portland cement industry is characterized by an intense energy consumption and responsible for about $7 \%$ of the total emission of anthropogenic $\mathrm{CO}_{2}$ in the world [1,2]. Thus, many studies have been conducted in search of alternatives to reduce the environmental impact linked to the cement industry. Among the measures that can be taken to reduce the environmental problems, is to partially replace the cement by industrial waste, such as blast furnace slag, fly ash, silica fume, rice husk ash and sugar cane bagasse ash [3-5]. The incorporation of waste in cementitious matrices reduces the consumption of cement, and helps to diminish environmental and economic problems associated with the final disposal of the waste.

The present paper investigates the effect of the partial cement replacement by stone cutting waste (SW) and ground waste clay brick (BW). Previous studies have classified wastes similar to SW as an addition chemically inert [6-8]. The use of this type of waste, in small amounts, resulted in an acceleration of hydration reactions at early ages, and did not affect the compressive strength and the Young's modulus [6-8]. The filler effect of this waste was responsible for this behavior.

Works with inert additions, such as quartz powder [9-10], limestone [10-13], rutile [14] and alumina [9], showed that the use of these materials promotes three main physical effects in cementitious systems. Two of these effects are cement dilution and modification of the spatial arrangement of the particles in the mixture and are a direct consequence of the substitution level. The third effect is the heterogeneous nucleation that is related to the surface area of the addition and, consequently, with the increasing of sites for hydration products of the cement.

The dilution effect is a consequence of the replacement of part of the cement by the same quantity of a mineral additive. Less cement implies a smaller amount of hydrated products and a lower compressive strength compared to the reference mixture [9-15]. The effect on the particles packing depends on the size, shape and texture of grains, and cement replacement content and it is related to the initial porosity of the mixture [15-16]. The heterogeneous nucleation is a physical process that leads to a chemical activation of cement hydration and is related to the hydrates nucleation on the outside of the mineral particles. It causes an accelerated cement hydration with an increase in compressive strength at a determined moment. According to several authors $[9,15,17]$, the nucleation phenomenon is most pronounced when the specific surface of the additive and the percentage of cement replacement are increased.

As regards to the BW, studies showed that besides the physical effect, the material also has a chemical effect and can be considered a pozzolan [18-22]. Pozzolans are materials when finely divided and in the presence of water are capable of reacting chemically with calcium hydroxide $(\mathrm{CH})$ to form compounds with cementitious properties. The main active phases of pozzolans are silica $\left(\mathrm{SiO}_{2}\right)$ and alumina $\left(\mathrm{Al}_{2} \mathrm{O}_{3}\right)$ amorphous [23-24]. The hydration products formed by the pozzolanic reactions are: calcium silicate hydrate, calcium aluminate hydrate and calcium alumino-silicate hydrates [24].

The pozzolanic reaction increases the compressive strength of cement-based materials by $\mathrm{CH}$ conversion leading to stronger prod- ucts and to a pore refinement. The effect is observed after a few days up to several months, depending mainly on the amount and solubility of the amorphous silica/alumina in the material [15]. The BW is considered a pozzolan of a low activity by reduced specific surface and low content of vitreous phase [22]. O'Farrell et al. [18] and Toledo Filho et al. [20] found that the replacement of up to $20 \%$ of Portland cement by BW in mortars promoted the maintaining or slight decrease in compressive strength and Young's modulus.

Recent works have shown that a combination of appropriate contents of a filler and a pozzolan can positively affect the mixture [12-13,15,25-27]. In other words, the filler improves the strength at early ages by the hydration reaction acceleration and the pozzolan contributes at older ages due to the pore refinement. The use of ternary mixtures can enable more efficient use of waste without compromising the mechanical properties of the cementitious product.

In this scope, this paper presents as objective to study two binary and one ternary mixtures containing SW and BW as partial replacement of the cement. The cement content selected for the replacement was $10 \%$ for SW and $20 \%$ for BW in binary and ternary mixtures. Thermal analyses (thermogravimetry and differential thermal analysis) were used to investigate the evolution of hydration reactions and pozzolanic activity of the waste. The packing density of the mixtures was determined according to the Compressible Packing Model, proposed by De Larrard [28]. In addition, the strength properties of the pastes were determined at ages of 7 and 28 days and were correlated with the hydration and packing of the pastes.

\section{Materials and methodology}

\subsection{Materials characterization}

For the production of the pastes Class G Portland cement (PC) [29], SW, BW, superplasticizer additive based on chains of modified poly carboxylic ether (aqueous solution containing $32.6 \%$ of solids), and deionized water were used. The stone waste used in

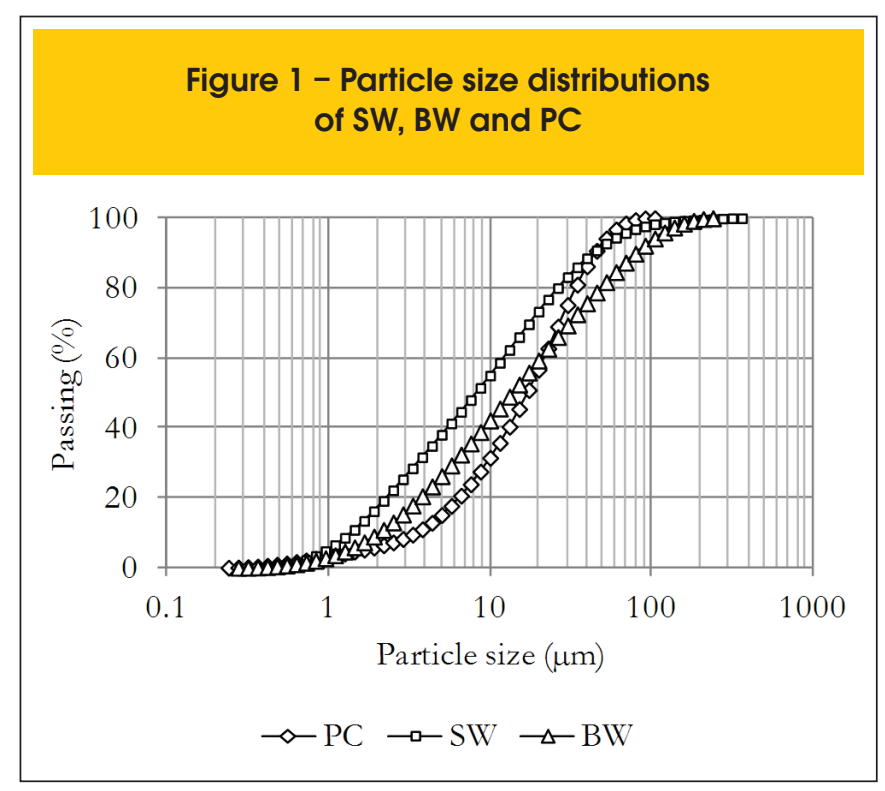




\begin{tabular}{|c|c|c|c|}
\hline \multicolumn{4}{|c|}{$\begin{array}{l}\text { Table } 1 \text { - Chemical composition (wt.\%) } \\
\text { and physical properties of SW, BW and PC }\end{array}$} \\
\hline Compound & sW & BW & PC \\
\hline $\mathrm{SiO}_{2}$ & 64.9 & 45.2 & 18.0 \\
\hline $\mathrm{Al}_{2} \mathrm{O}_{3}$ & 17.0 & 36.8 & 4.1 \\
\hline $\mathrm{K}_{2} \mathrm{O}^{0}$ & 9.3 & 8.6 & 0.5 \\
\hline $\mathrm{Fe}_{2} \mathrm{O}_{3}$ & 3.7 & 2.2 & 5.4 \\
\hline $\mathrm{CaO}$ & 3.0 & 0.5 & 67.4 \\
\hline $\mathrm{SO}_{3}$ & 1.5 & 1.7 & 3.7 \\
\hline Loss on ignition & 0.6 & 5.1 & 0.8 \\
\hline Density $\left(\mathrm{kg} / \mathrm{m}^{3}\right)$ & 2.72 & 2.55 & 3.23 \\
\hline Virtual packing density & 0.55 & 0.42 & 0.55 \\
\hline $\mathrm{D}_{50}{ }^{*}(\mu \mathrm{m})$ & 8.2 & 13.7 & 17.0 \\
\hline \multicolumn{4}{|c|}{ * $50 \%$ passing size in the cumulative distribution. } \\
\hline
\end{tabular}

this work was generated during the cutting of blocks from mylonite gnaise, collected from a sedimentation tank of a plant in Santo Antônio de Pádua/RJ-Brazil. After collection, the waste was dried in a ventilated oven at $110^{\circ} \mathrm{C}$ and then disaggregated in a ball mill Pavitest for 20 min (600 RPM). The clay brick waste was collected from four ceramic industries in Campos dos Goytacazes/RJ-Brazil. After the homogenization, the material was triturated in a jaw crusher Pulverisette 1 Fritsch type, and then ground in a Pavitest ball mill for 1 hour (1,800 RPM).

The particle size distribution of the materials was measured by a laser diffraction particle size analyzer Mastersizer 2000 (Malvern Instruments). The granulometric curves of the SW, BW and cement are presented in Figure 1. The SW was the material that presented a finer grain size, followed by PC and BW. Table 1 shows the main physical characteristics and chemical composition of SW, BW and PC. The density was determined in a gas pycnometer (Micromeritics AccuPyc 1340). The virtual packing density of the

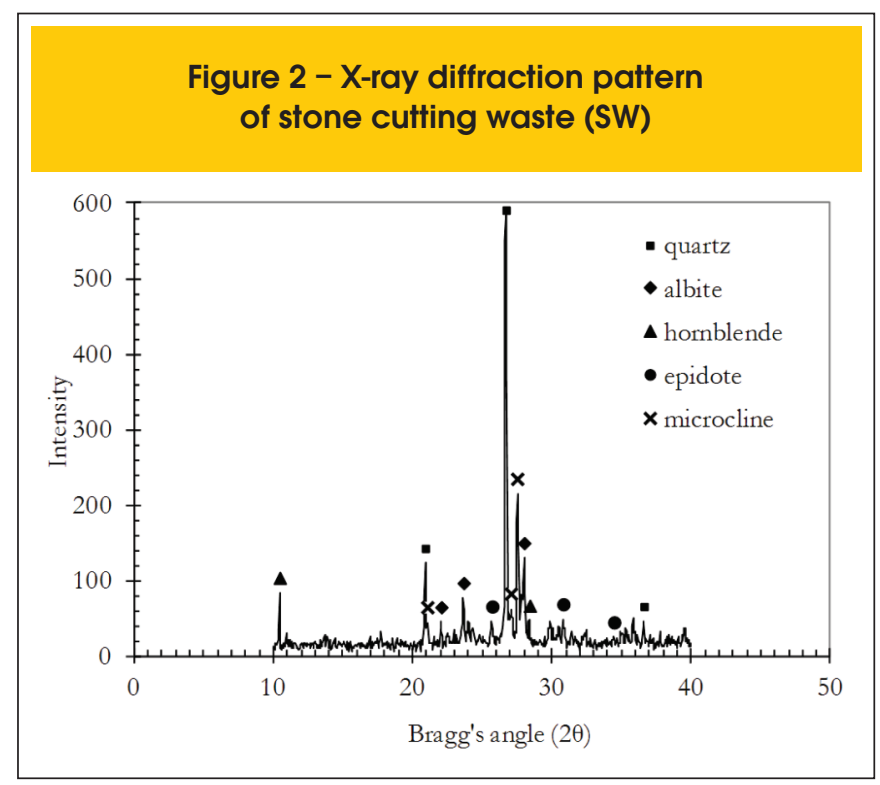

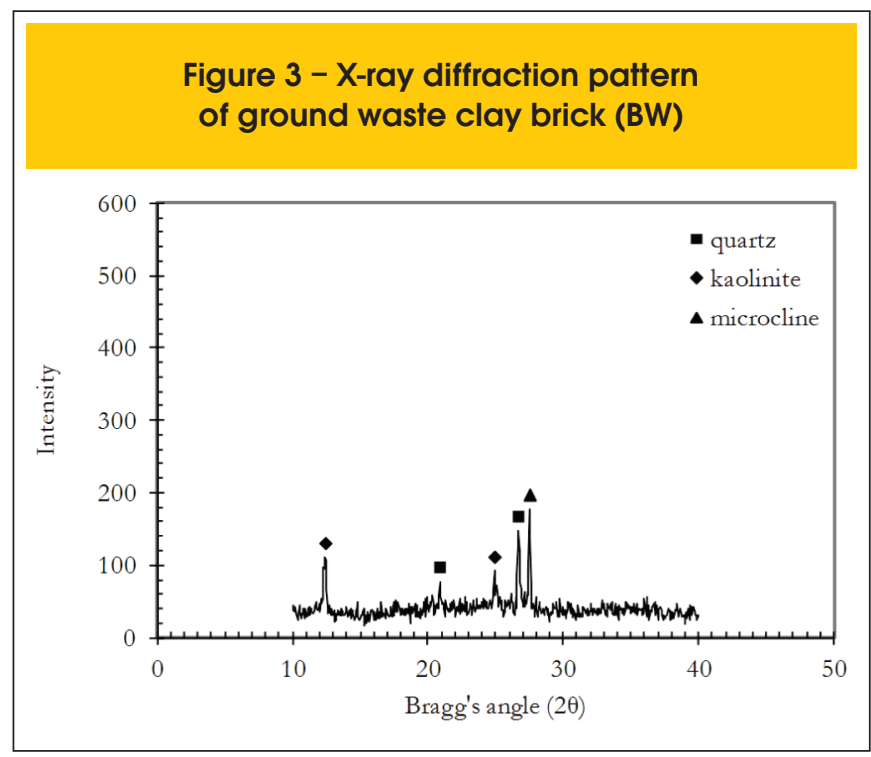

materials was determined from water demand test according to the procedures suggested by de Larrard [28]. The chemical composition was determined by X-ray fluorescence spectrometer (Shimadzu EDX-720).

The mineralogical composition was determined on a BRUKER diffractometer, model D8 FOCUS with copper radiation (Cuka, $\lambda=$ $1.5418 \AA$ ). Figure 2 shows the $\mathrm{X}$-ray diffraction pattern presented by SW, where the crystalline phases identified are typical of gneiss. Figure 3 shows the X-ray diffraction pattern of BW, where the main crystalline phases found were quartz, microcline and kaolinite.

Figure 4 presents the thermogravimetry (TG) and the derivative thermogravimetry (DTG) curves of PC, SW and BW. In this case, it is observed that the BW mass losses occurred at around $468^{\circ}$ $\mathrm{C}$, that corresponds to the transformation of kaolin into metakaolin, which shows that the firing process of the ceramic material was not sufficiently effective to promote the complete dehydroxylation of the clay mineral [30].

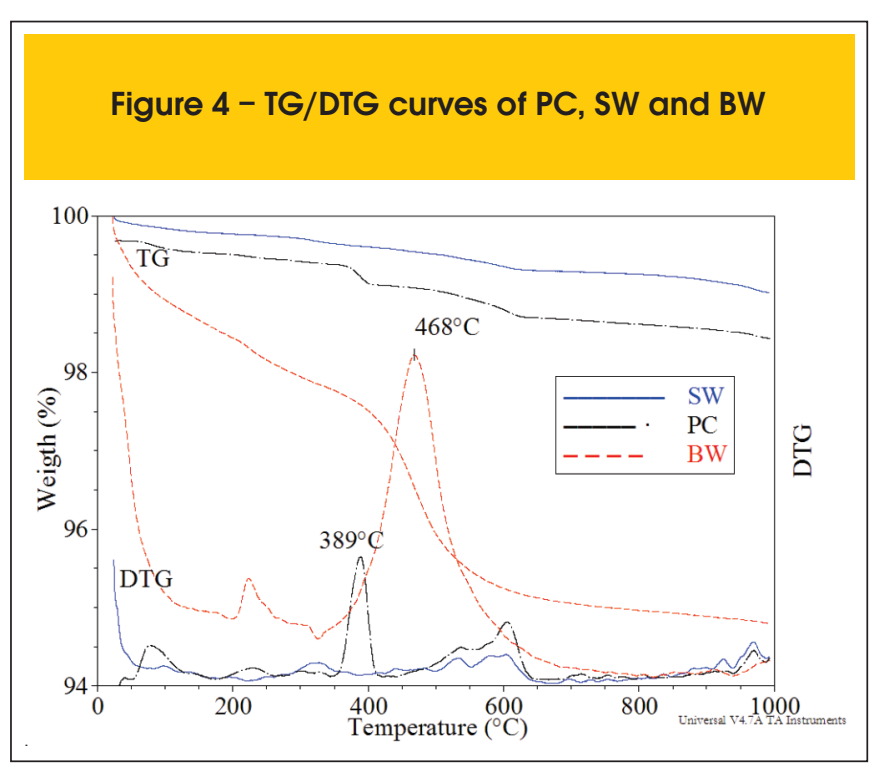




\subsection{Mix design and production of the pastes}

Four pastes with water-cementitious materials ratio of 0.47 and different contents of replacement cement mass were designated as follows: reference paste with cement and water (RF-PC); paste with $10 \%$ cement replacement by SW (SW-PC); paste with $20 \%$ of cement replacement by BW (BW-PC); and ternary paste with $30 \%$ of cement replacement, $10 \%$ by SW and $20 \%$ by BW (SW-BW-PC). The pastes consistency was evaluated by the Kantro method [31], and it was adjusted for $100 \pm 10 \mathrm{~mm}$ with the use of specific levels of superplasticizer. Table 2 shows the constituents of the pastes.

For the paste production, water and superplasticizer were placed in a mixer, which was rotated initially at a speed of 4,000 RPM. Then, the solids, previously homogenized, were added to the cup in $15 \mathrm{sec}$. After that, the paste was mixed for another $2 \mathrm{~min}$, left to stand for $4 \mathrm{~min}$ and mixed again for $30 \mathrm{sec}$. Small samples for thermal analysis testing were placed in polypropylene bags immediately after mixing and were cured at $23^{\circ} \mathrm{C}$ until the moment of conducting the tests. For tests of compressive strength, the pastes were poured into cylindrical molds $(50 \mathrm{~mm}$ diameter and $100 \mathrm{~mm}$ in height) and compacted in two layers with a glass rod with $6 \mathrm{~mm}$ diameter for $45 \mathrm{sec}$ in each layer. Then, the molds were covered with plastic wraps and placed in a humid environment. After 24 hours, the specimens were removed from the molds, sealed with plastic wraps and kept under curing in a wet environment with average temperature of $23^{\circ} \mathrm{C}$ until being tested.

\subsection{Mechanical properties}

The compressive strength of the pastes was evaluated by the failure of 4 specimens for each mixture, at the ages of 7 and 28 days, in a universal testing machine Shimadzu UH-F1000kN with a loading speed of $0.3 \mathrm{~mm} / \mathrm{min}$. The axial strain was calculated from the average reading of two electric displacement transducers, fixed lengthwise and diagonally to each other in the central region of the specimen. With the stress-strain curve it was possible to calculate the secant modulus of elasticity. The results of the compressive strength and Young's modulus were statistically analyzed by Analysis of Variance (ANOVA) at $5 \%$ probability test followed by Tukey test.

\subsection{Thermogravimetry and differential thermal analysis}

The thermal analyzes were performed in a TA Instruments Q600 SDT equipment with the following experimental conditions: con-

Table 2 - Mix design of the pastes

\begin{tabular}{ccccc} 
Pastes & \multicolumn{5}{c}{ Proportions of the materials (wt.\%) } \\
& PC & SW & BW & SP* (\%) \\
RF-PC & 1.00 & - & - & - \\
SW-PC & 0.90 & 0.10 & - & 0.03 \\
BW-PC & 0.80 & - & 0.20 & 0.06 \\
SW-BW-PC & 0.70 & 0.10 & 0.20 & 0.10 \\
* The superplasticizer is specified as the solid mass.
\end{tabular}

stant heating rate of $10^{\circ} \mathrm{C} / \mathrm{min}$; temperature between 22 and $1000^{\circ} \mathrm{C}$, nitrogen flow of $100 \mathrm{~mL} / \mathrm{min}$; reference of $\alpha-\mathrm{Al}_{2} \mathrm{O}_{3}$; sample mass of about $10 \mathrm{mg}$, and open pan of platinum. The pastes were maintained at $35^{\circ} \mathrm{C}$ isotherm for 1 hour inside the equipment to liberate the free water. The analyzes were conducted for the raw materials (cement, SW, and BW) and for the different pastes at the ages of $1,3,7$ and 28 days.

The identification of the formed compounds was performed using the peak temperatures of derivative thermogravimetry (DTG) and differential thermal analysis (DTA) curves. According to the literature [24,32], the typical peaks in DTG and DTA curves in a cement matrix are: ettringite (AFt phase) at 76 to $84^{\circ} \mathrm{C}$; calcium silicate hydrate (C-S-H) at 104 to $140^{\circ} \mathrm{C}$; calcium alumino silicate hydrate $(\mathrm{CASH})$ at 157 to $163^{\circ} \mathrm{C}$; calcium aluminate hydrate $(\mathrm{CAH})$ at 230 to $240^{\circ} \mathrm{C}$; portlandite $(\mathrm{CH})$ at 460 to $465^{\circ} \mathrm{C}$; and calcite (CČ) at 620 to $645^{\circ} \mathrm{C}$.

The quantification of the products formed in the pastes was carried out using temperature ranges in the TG curve. To obtain the mass loss due to dehydration of AFt, C-S-H, CAH and CASH was considered the TG curve in the range from $35^{\circ} \mathrm{C}$ to the temperature of onset of dehydration of $\mathrm{CH}$. The mass loss due to dehydration of $\mathrm{CH}$ and decarbonation of $\mathrm{CC}$ were obtained from the range delimited by their referred peaks in the DTG curve. With the exception of $\mathrm{CH}$ and $\mathrm{C} \check{C}$, the mass loss of other hydrated compounds occurs in temperature ranges that may overlap, making it difficult to identify and quantify these phases separately.

With the weight loss obtained in the TG curves quantities of chemically combined water, in calcined basis, were calculated for each paste according to the procedures recommended by Dweck et al. [33]. The content of the $\mathrm{CH}$ was estimated from the dehydration reaction (Reaction 1) and the content of the CČ was estimated from the descarbonation reaction (Reaction 2).

$$
\begin{aligned}
& \mathrm{Ca}(\mathrm{OH})_{2} \rightarrow \mathrm{CaO}+\mathrm{H}_{2} \mathrm{O} \\
& 100 \% \rightarrow 75.68 \%+24.32 \%
\end{aligned}
$$

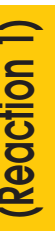

$$
\begin{aligned}
\mathrm{CaCO}_{3} & \rightarrow \mathrm{CaO}+\mathrm{CO}_{2} \\
100 \% & \rightarrow 56.00 \%+44.00 \%
\end{aligned}
$$

\subsection{Packing density}

The Compressible Packing Model (CPM) proposed by De Larrard [28] was used to characterize the packing density of the dry granular mixture of the pastes. In this model, the packing of the particles depends on the size, the grain shape and the adopted method of the packing. The CPM allows making the transition from virtual packing density $(\gamma)$ to the actual packing density $(\varnothing)$ of the mixture, which is in accordance with the energy applied and the placing time of the particles. For the CPM, a coefficient of packing $(\mathrm{K})$ establishes the connection between the virtual packing density and 


\section{Figure 5 - Stress versus strain curves of the pastes for the (a) 7 days (b) and 28 days age}

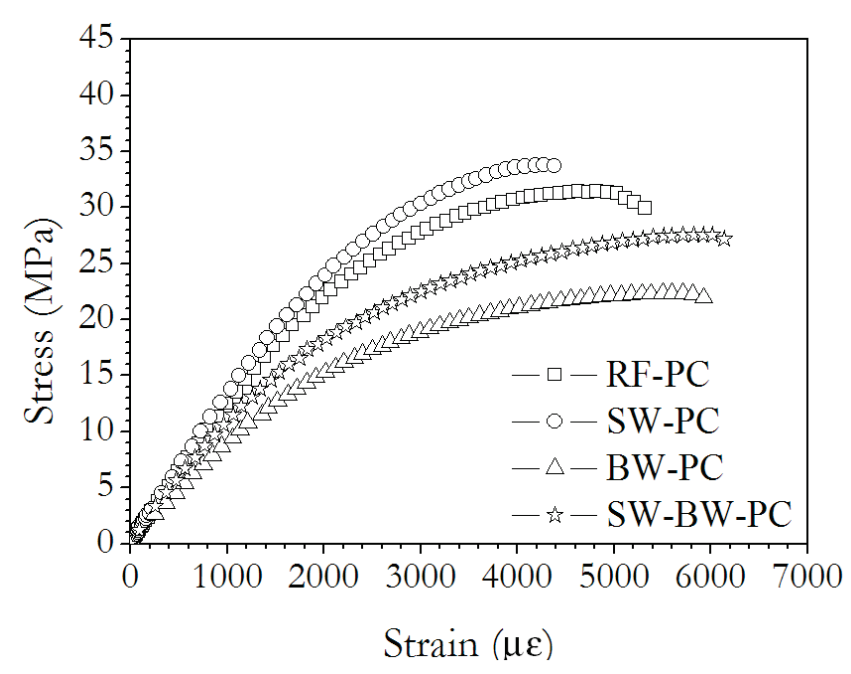

(A)

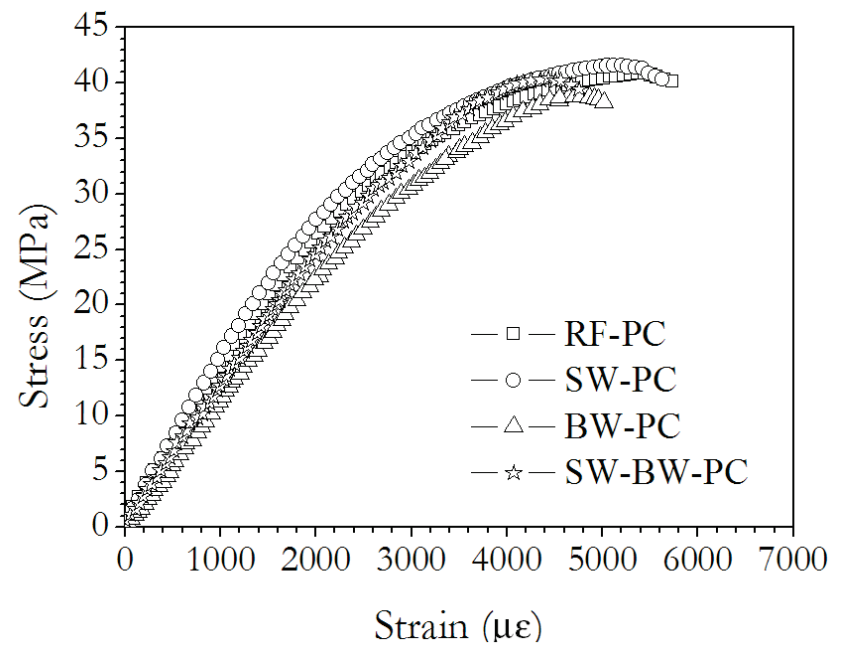

B the actual packing density of a given mixture. The index $\mathrm{K}$ is strictly dependent on the protocol adopted for packing of the mixture, and when $\mathrm{K}$ tends to infinity, $\varnothing$ tends to $\mathrm{Y}$. For thin materials, $\mathrm{K}$ assumes a value of 6.7 , since the placing process is the water demand test [28]. The general equation that establishes the correlation between $\varnothing$ and $\gamma$ is given by:

$$
\mathrm{K}=\sum_{\mathrm{i}=1}^{\mathrm{n}} \frac{\mathrm{y}_{\mathrm{i}} / \beta_{\mathrm{i}}}{\phi}-\frac{1}{\gamma^{(\mathrm{i})}}
$$

Where: $\mathrm{n}$ is the number of grain classes; $\mathrm{y}_{\mathrm{i}}$ is the volumetric fraction; $\beta_{\mathrm{i}}$ is the virtual packing density of the ith class. It represents the volume of grains contained in a unitary volume, compacted with an ideal energy that corresponds to a maximum virtual packing, and $\gamma^{(i)}$ is a virtual packing density when $i$ is the dominant class. When Equation 2 is used with $n=1$, it is possible to determine the $\beta_{i}$ for the class unit using:

$$
\beta=\frac{1+K}{K} \phi
$$

\section{Results and discussion}

\subsection{Mechanical properties}

The typical stress-strain curves of the pastes studied at the ages of 7 and 28 days of curing are presented in Figure 5. Table 3 presents the average values of compressive strength and Young's modulus. The substitution of $10 \%$ of PC by SW did not significantly influence the compressive strength in relation to the reference paste at both ages (probability $\leq 0.05$ ). For the paste with $20 \%$ of replacement of $\mathrm{PC}$ by $\mathrm{BW}$, the values of the compressive strength were significantly lower at the ages 7 and 28 days (reductions of 27 and 10\%, respectively). Similar results were observed by Toledo Filho et al. [20] who studied the replacement of the PC for several levels for

Table 3 - Average values of compressive strength and Young's modulus of the pastes at ages of 7 and 28 days (coefficients of variation CV are indicated within parentheses)

\begin{tabular}{ccccc} 
& \multicolumn{2}{c}{ Compressive strength (MPa) - CV (\%) } & \multicolumn{2}{c|}{ Young's modulus (GPa) - CV (\%) } \\
Pastes & 7 days & 28 days & 7 days & 28 days \\
& $31.64(0.92)$ & $41.33(1.25)$ & $12.29(1.08)$ & $14.06(2.14)$ \\
RF-PC & $32.04(5.02)$ & $40.40(3.07)$ & $14.19(4.36)$ & $15.56(2.45)$ \\
SW-PC & $22.83(3.82)$ & $37.03(4.03)$ & $9.38(3.08)$ & $11.34(4.25)$ \\
BW-PC & $26.70(3.62)$ & $39.66(2.32)$ & $10.26(4.08)$ & $13.08(2.74)$ \\
SW-BW-PC & & &
\end{tabular}




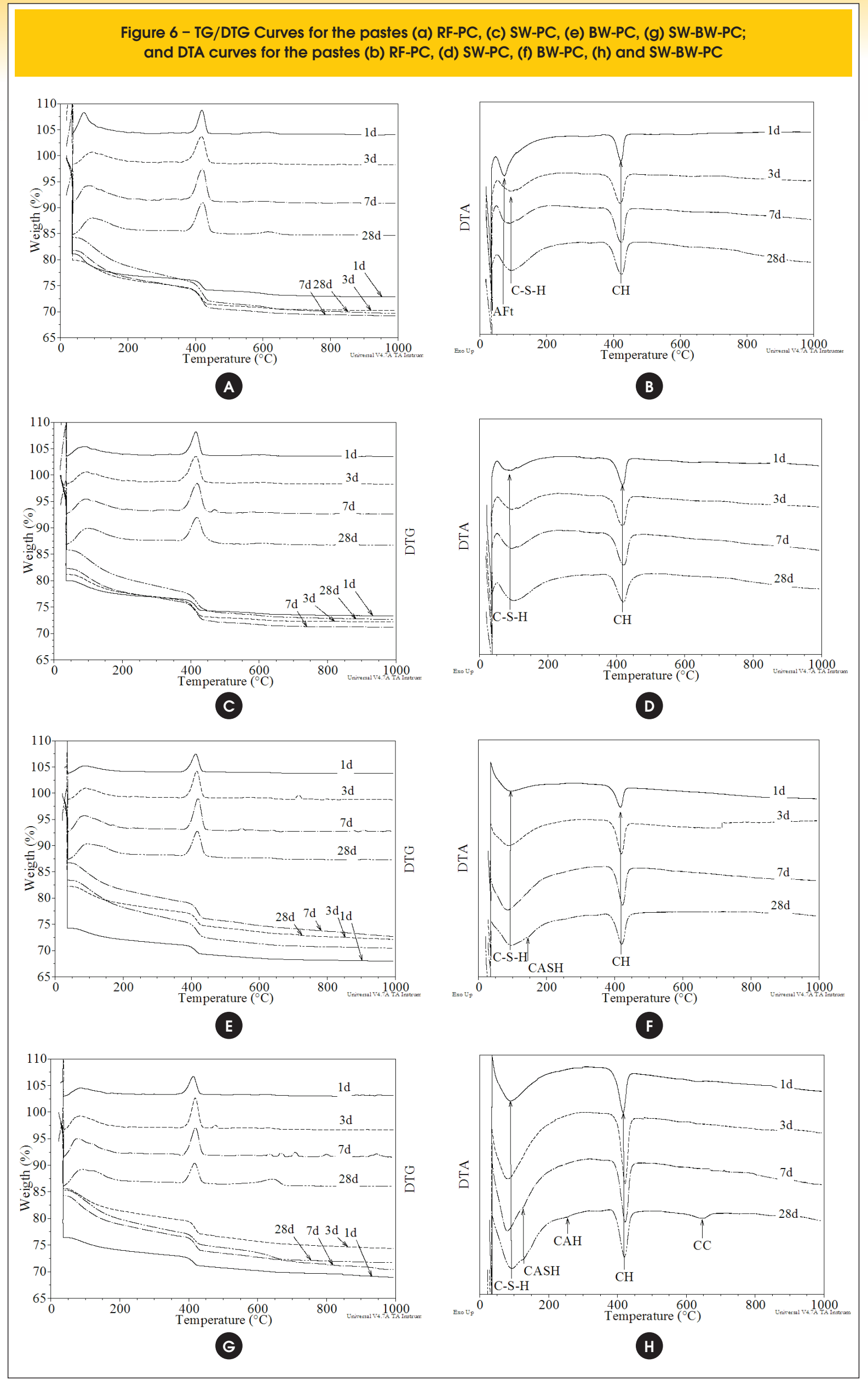


calcined clay brick waste in concretes and mortars. In the paste SW-BW-PC, at the age of 7 days, there was a reduction of approximately $16 \%$ in compressive strength compared to that of the reference paste. At the age of 28 days, there were no significant differences between RF-PC and SW-BW-PC pastes.

In case of the Young's modulus, for the paste BW-PC a significantly reduction was observed in relation to the reference paste at both ages of curing. Gonçalves et al. [21] also observed mortars with a higher strain when the cement was partially replaced by ground clay brick and attributed this phenomenon to the lamellar structure of the metakaolin, which favors the strain under load.

Increases in the Young's modulus values were observed at the ages 7 and 28 days of curing for the SW-PC paste, when compared to the reference paste. An increase in the modulus also was verified by Almeida et al. [8] who used low levels of rock cutting waste in cementitious matrices. For the SW-BW-PC paste, there was a reduction in modulus compared to the reference paste; however, this decrease was smaller than that of the BW-PC paste. This effect is associated with the combination of two residues, in other words, the use of SW reduced the negative effect of the BW in the modulus. The results for both Young's modulus and compressive strength are consistent with the literature [6-8,18-22].

\subsection{Thermogravimetry and differential thermal analysis}

The results of TG/DTA and DTG of the pastes RF-PC, SW-PC, BW-PC, and SW-BW-PC at the ages of 1, 3, 7 and 28 days of curing are shown in Figure 6. For all pastes three transitions of mass loss in the TG curve were observed. The first transition occurred between 35 and $420^{\circ} \mathrm{C}$, the second between 420 and $500^{\circ} \mathrm{C}$ and a third between 500 and $1000^{\circ} \mathrm{C}$. DTG and DTA curves were used to identify the phases present in each paste. In the paste RF-PC, at 1 day of age, peaks were observed related to the ettringite and the $\mathrm{C}-\mathrm{S}-\mathrm{H}$ (overlapping peaks), and the $\mathrm{CH}$. At 3 days, the $\mathrm{CH}$ and $\mathrm{C}$ $\mathrm{S}-\mathrm{H}$ peaks increased and the peak of AFt decreased, as expected. In the pastes SW-PC at all ages DTG and DTA curve peaks, associated with $\mathrm{C}-\mathrm{H}-\mathrm{S}$ at the first transition and the $\mathrm{CH}$ at the second transition, were identified. In the BW-PC paste at the ages of 1, 3 and 7 days peaks associated with $\mathrm{C}-\mathrm{H}-\mathrm{S}$ and $\mathrm{CH}$ were identified. In the same paste, at the 28 days age, a peak was also identified, probably related to $\mathrm{CASH}$ due to the significant presence of $\mathrm{Al}_{2} \mathrm{O}_{3}$ in the chemical composition of the BW (Table 1). The SW-BW-PC paste presented at the ages of 1 and 3 days peaks associated with $\mathrm{C}-\mathrm{S}-\mathrm{H}$ and $\mathrm{CH}$. At the age of 7 days, a peak was related to the $\mathrm{CASH}$. At the age of 28 days, beside the peaks shown in other ages, in the SW-BW-PC paste peaks were identified associated with $\mathrm{CAH}$ and CČ. In comparing the graphs DTG and DTA, for all pastes containing $\mathrm{BW}$ at the age of 28 days, there was a reduction of the intensity of the peak of $\mathrm{CH}$ compared to the same pastes of 7 days age, which is an indicative of pozzolanic reactions.

The calculated values of water chemically combined with ettringite, $\mathrm{C}-\mathrm{S}-\mathrm{H}, \mathrm{CAH}$ and $\mathrm{CASH}$; with $\mathrm{CH}$; and $\mathrm{CO}_{2}$ combined with $\mathrm{CC}$, for all pastes, are presented in Table 4. The RF-PC paste showed, as expected, an increase in the amount of water combined with ettringite, $\mathrm{C}-\mathrm{S}-\mathrm{H}, \mathrm{CAH}$ and $\mathrm{CASH}$, and in the amount of $\mathrm{CH}$ with increasing age. The SW-PS paste, at the age of 1 day, produced about $12 \%$ more $\mathrm{CH}$ in relation to the reference paste. At the age of 3 days, there was a reduction of $5 \%$ in the amount of $\mathrm{CH}$ in relation to the reference paste, and for 7 and 28 days of curing, this reduction increased to $7 \%$ and $10 \%$, respectively. As the level of cement replacement of this paste was $10 \%$, it was observed that the residue did not show pozzolanic activity, because the reduction in the amount of $\mathrm{CH}$ at 28 days was approximately equal to the

Table 4 - Chemically combined water content with the compounds AFt, C-S-H, CAH and CASH; content of CH and CČ (wt.\%)

\begin{tabular}{|ccccc|} 
Pastes & Age & $\begin{array}{c}\text { Combined water with } \\
\text { AFt, C-S-H, CASH, CAH (\%) }\end{array}$ & CH (\%) & Č (\%) \\
RF-PC & 1 & 6.91 & 11.10 & 2.01 \\
& 3 & 7.27 & 20.52 & 1.61 \\
& 7 & 10.31 & 24.26 & 1.98 \\
SW-PC & 28 & 11.38 & 26.44 & 2.88 \\
& 1 & 4.79 & 12.53 & 1.33 \\
& 3 & 6.59 & 19.36 & 1.23 \\
BW-PC & 7 & 8.73 & 22.52 & 1.54 \\
& 28 & 10.33 & 23.87 & 1.38 \\
& 1 & 3.77 & 10.33 & 1.45 \\
SW-BW-PC & 3 & 5.85 & 14.70 & 3.08 \\
& 7 & 9.22 & 18.39 & 3.81 \\
& 1 & 10.72 & 19.66 & 3.46 \\
& 3 & 4.07 & 11.29 & 2.66 \\
& 7 & 6.91 & 15.59 & 4.12 \\
& 28 & 9.93 & 16.31 & 4.61 \\
\hline
\end{tabular}


replacement level. The SW interfered only with an acceleration of reactions of hydration in the early ages, which may be attributed to the effect caused by heterogeneous nucleation of fine particles of a waste. The heterogeneous nucleation phenomenon was also observed by Lawrence et al. [9] and Cyr et al. [15], who have studied the partial replacement of cement by inert additions with average size less than $61 \mu \mathrm{m}$.

Pastes SW-BW-PC and BW-PC, on the other hand, produced similar amounts of $\mathrm{CH}$ in relation to the reference paste, at the age of 1 day, even when containing a smaller amount of cement. This probably happened due to the acceleration in the hydration reactions caused by fine particles of the waste; this effect was less pronounced in the paste containing only BW, because of its smaller amount of fine particles (see Figure 1). At the ages of 3, 7 and 28 days, the paste BW-PC showed reductions of $28 \%, 24 \%$ and $25 \%$ of $\mathrm{CH}$ content, respectively, in relation to the reference paste. For the SW-BW-PC paste, at the age of 3 days, there was a reduction of $24 \%$ of $\mathrm{CH}$ in relation to the RF-PC. At the age of 7 and 28 days, the reductions were of 32 and $44 \%$, respectively. In the BW-PC and SW-BW-PC pastes, the reduction in $\mathrm{CH}$ content was higher than the level of substitution of cement $(20 \%$ and $30 \%$, respectively). With this, it was possible to infer that the BW presented pozzolanic activity. For the content of substitution studied in this work, the BW was more reactive in the presence of SW. This fact was also verified by Antoni et al. [27] who studied ternary mixtures with filler and pozzolan. This effect is very complex and can be attributed to acceleration in the hydration reactions caused by SW finer particles that accelerated the consumption of $\mathrm{CH}$ by de BW and also by the insertion of additional sites promoted by the SW for the nucleation of hydrated phases.

An analysis can be carried out by calculating the amount of $\mathrm{CH}$ in pastes, at the age of 28 days, with respect to the initial mass of cement. In this case, it was observed that the levels of $\mathrm{CH}$ calculated for the different pastes were $26 \%$ for RF-PC, $26 \%$ for SW-PC, $24 \%$ for BW-PC and $20 \%$ for SW-BW-PC. These numbers show clearly the reduction in $\mathrm{CH}$ content when the $\mathrm{BW}$ and character inert of the SW were used.
In the case of chemically combined water with AFt, C-S-H, CAH and $\mathrm{CASH}$, for 1 day of curing, the pastes SW-PC, BW-PC and SW-BWPC presented reductions of $30 \%, 45 \%$ and $41 \%$, respectively, in relation to the RF-PC, which is indicating a change in the hydration kinetics, because these reductions were higher than substitution levels of PC. For 3 and 7 days of curing, the content of chemically combined water has been reduced by $9 \%$ and $19 \%$ in SW-PC and BW$\mathrm{PC}$ pastes, respectively, compared to RF-PC. These values were approximately equal to the contents of cement replacement in these pastes. In the paste SW-BW-PC, for the two ages, the decrease was only $5 \%$ compared to the reference mixture.

At 28 days, the SW-PC paste presented a chemically combined water content of $10 \%$ less than the reference paste, which corresponded exactly to the cement replacement level in this paste. The same decrease was observed for the $\mathrm{CH}$. BW-PC and SW-BWPC presented $5 \%$ and $4 \%$ of reduction, respectively, in chemically combined water content compared to the RF-PC. As the cement replacement content of these pastes were $20 \%$ and $30 \%$ respectively, it can be said that part of the $\mathrm{CH}$ produced in BW-PC and SW-BW-PC pastes reacted with BW and water to form C-S-H, $\mathrm{CASH}$ and $\mathrm{CAH}$. Regarding the CČ, there was an increase in the amount for higher curing times due to carbonation $\mathrm{CH}$, probably during handling of the samples.

\subsection{Packing density}

The RF-PC, SW-PC, BW-PC and SW-BW-PC pastes presented packing densities equal to $0.55,0.55,0.52$ and 0.53 , respectively. From these results it can be stated that the addition of $10 \%$ of SW (SW-PC paste) did not modify the packing density of the dry mixture, compared to the reference paste. It is important to note that although the SW had a density lower than the cement, the virtual packing density of the dry mix had not changed for the replacement level observed. This occurred because the values of packing density of the BW and cement were similar. This fact caused that the compressive strength was maintained, since consumption of $\mathrm{CH}$ by the SW had not been verified.

Figure 7 - Relationship of packing density and compressive strength of pastes for 7 and 28 days age

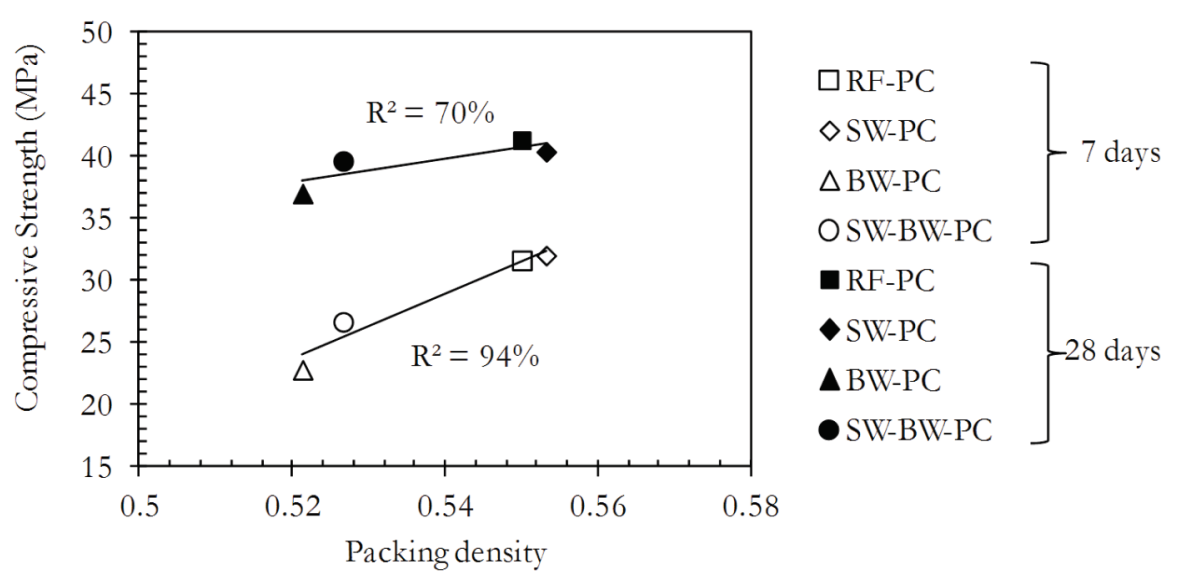


The partial replacement of PC by BW (BW-PC paste) reduced the packing density of this paste in relation to the RF-PC. BW and cement have similar granulometric curves (Figure 1), however, the BW has packing density lower than the cement, leading to a reduced packing density of the dry mixture. This behavior, has certainly contributed to reducing the compressive strength of the BW$\mathrm{PC}$ paste as compared to the reference.

In the SW-BW-PC paste, the packing density of the mixture was higher than that of the BW-PC paste, but lower than the reference paste. In this paste a higher consumption of $\mathrm{CH}$ was also observed in comparison with the BW-PC paste. Thus, the reduction in packing of the ternary mixture, in relation to the RF-PC, was compensated by the pozzolanic activity of BW, what caused the maintenance of the compressive strength in relation to the reference paste. Maintenance of the compressive strength was also observed by Cyr et al. [25], Ghrici et al. [26], and Antoni et al. [27], who studied the combination of inert and pozzolanic waste.

Figure 7 presents the correlation between the values of the packing density and compressive strength of the studied pastes. As can be seen, for 7 days there was a good linear fit between the packing density and compressive strength $\left(R^{2}=94 \%\right)$. This behavior was similar to that observed for mortars with cement replacement by sugar cane bagasse ash [34]. However, for 28 days the correlation coefficient was $70 \%$, which indicates a contribution of the pozzolanic reactions of $\mathrm{BW}$ in the compressive strength of the pastes, as confirmed by the results of thermogravimetry (Table 4). With regards to the influence of packing granular on the hydration of the mixtures, no trend was observed while varying the packing of mixtures from 0.52 to 0.55 .

\section{Conclusions}

From the test results, for the replacement level studied, it was concluded that:

- In the paste SW-PC, there was an acceleration effect in the hydration reactions until the age of 7 days, compared to reference paste. At 28 days, there was a reduction in the levels of $\mathrm{CH}$ and chemically combined water in the same proportion of cement replacement, which revealed the character inert of the SW. However, the SW-PC paste achieved compressive strength and packing density similar to the reference paste. This behavior can be attributed to the effect filler of the SW;

- In the paste BW-PC, a small acceleration of hydration reactions was also observed at early ages. Reductions in the amount of $\mathrm{CH}$ higher than the level of substitution of cement and formation of new phases hydrated ( $\mathrm{CASH}$ and $\mathrm{CAH}$ ) also were observed at the age of 28 days. The amount of water combined with AFt, $\mathrm{C}-\mathrm{S}-\mathrm{H}, \mathrm{CAH}$ and $\mathrm{CASH}$ was reduced to lower levels than cement replacement by BW. The reduction in the amount of $\mathrm{CH}$ and the increase in the amount of combined water indicated that the BW had pozzolanic activity. However, the packing density of BW-PC paste was lower than that of the reference paste and a decrease of compressive strength occurred. In other words, the pozzolanic activity was not enough to offset the reduction in the amount of hydrated products and the lower packing density of this mixture;

- In the SW-BW-PC paste, the use of both residues promoted similar resistance as the reference paste at age of 28 days. The SW improved packing density of the pastes and the BW contrib- uted to the pozzolanic activity. The ternary mixture presented an advantage over the binary mixtures, because the highest level of substitution was used and the mechanical properties were not significantly modified. The use of ternary mixture can allow more efficient use of mineral resources and better use of the waste.

\section{Acknowledgments}

The authors would like to thank FAPERJ, CAPES and CNPq for the financial support and the Laboratory of Civil Engineering at UENF where the grinding of the wastes was carried out.

\section{References}

[01] MEHTA, P. K., MONTEIRO, P. J. M. Concreto. Microestrutura, propriedades e materiais. São Paulo: IBRACON, 2008, 674 p.

[02] MALHOTRA, V. M. Introduction: sustainable development and concrete technology. Concrete International, v.24, n.7, 2002, pp. 22

[03] MALHOTRA, V. M., MEHTA, P. K. Pozzolanic and cementitious materials, $1^{\text {st }}$ ed., Gordon and Breach Publishers: Amsterdam, 1996, $191 \mathrm{p}$.

[04] CORDEIRO, G. C., TOLEDO FILHO, R. D., FAIRBAIRN, E. M. R. Use of ultrafine rice husk ash with high-carbon content as pozzolan in high performance concrete. Materials and Structures, v.42, 2009, pp. 983-992.

[05] CORDEIRO, G. C., TOLEDO FILHO, R. D., FAIRBAIRN, E. M. R. Cinza ultrafina do bagaço de cana-de-açúcar: material pozolânico de alto potencial para países tropicais. Revista IBRACON de Estruturas e Materiais, v.3, n.1, 2010, pp. 50-67.

[06] ALMEIDA, N., BRANCO, F., SANTOS, J. R. Recycling of stone slurry in industrial activities: Application to concrete mixtures. Building and Environment, v.42, n.2, 2007, pp. 810-819.

[07] CELIK, T., MARAR, K. Effects of crushed stone dust on some properties of concrete. Cement and Concrete Research, v.26, n.7, 1996, pp. 1121-1130.

[08] ALMEIDA N., BRANCO F., DE BRITO J., SANTOS, J. R. High-performance concrete with recycled stone slurry. Cement and Concrete Research, v.37, n.2, 2007, pp. 210-220.

[09] LAWRENCE, P., CYR, M., RINGOT, E. Mineral admixtures in mortars - Effect of inert materials on short-term hydration. Cement and Concrete Research, v.33, n.12, 2003, pp. 1939-1947.

[10] RAHHAL, V., TALERO, R. Early hydration of Portland cement with crystalline mineral additions. Cement and Concrete Research, v.35, n.7, 2005, pp. 1285-1291.

[11] SOROKA, I., SETTER, N. The effect of fillers on the strength of cement mortars, Cement and Concrete Research, v.7, n.4, 1977, pp. 449-456.

[12] MENÉNDEZ, G., BONAVETTI, V., IRASSAR, E. E. Strength development of ternary blended cement with limestone filler and blast-furnace slag. Cement and Concrete Composites, v.25, n.1, 2003, pp. 61-67. 
[13] CARRASCO, M. F., MENÉNDEZ, G., BONAVETTI, V., IRASSAR, E. F. Strength optimization of "tailor-made cement" with limestone filler and blast furnace. Cement and Concrete Research, v.35, n.7, 2005, pp. 1324-1331.

[14] GUTTERIDGE, W.A., DALZIEL, J.A. Filler cement: the effect of the secondary component on the hydration of Portland cement: Part 1. A fine non-hydraulic filler, Cement and Concrete Research, v.20, n.5, 1990, pp. 778-782.

[15] CYR, M., LAWRENCE, P., RINGOT, E. Mineral admixtures in mortars: Quantification of the physical effects of inert materials on short-term hydration. Cement and Concrete Research, v.35, n.4, 2005, pp. 719-730.

[16] CORDEIRO, G. C., TOLEDO FILHO, R. D., TAVARES, L. M., FAIRBAIRN, E. M. R. Pozzolanic activity and filler effect of sugar cane bagasse ash in Portland cement and lime mortars. Cement and Concrete Composites, v.30, n.5, 2008, pp. 410-418.

[17] NEVILLE, A.M. Properties of Concrete, 4th edition, John Wiley \& Sons, New York, 1996

[18] O'FARRELL, M., WILD, S., SABIR, B. B. Pore size distribution and compressive strength of waste clay brick mortar. Cement and Concrete Composites, v.23, n.1, 2001, pp. 81-91.

[19] KHATIB, J. M. Properties of concrete incorporating fine recycled aggregate. Cement and Concrete Research, v.35, n.4, 2005, pp. 763-769.

[20] TOLEDO FILHO, R. D., GONÇALVES J. P., AMERICANO B. B., FAIRBAIRN E. M. R. Potential for use of crushed waste calcined-clay brick as a supplementary cementitious material in Brazil. Cement and Concrete Research, v.37, n.9, 2007, pp. 1357-1365.

[21] GONÇALVES, J. P. TAVARES L. M., TOLEDO FILHO R.D., FAIRBAIRN E. M. R. Performance evaluation of cement mortars modified with metakaolin or ground brick. Construction and Building Materials, v.23, n.5, 2009, pp. 1971-1979.

[22] GONÇALVES, J. P. Desenvolvimento e caracterização de concretos de baixo impacto ambiental e contendo argila calcinada e areia artificial. Tese (Doutorado) Rio de Janeiro, 2005, Universidade Federal do Rio de Janeiro - COPPE/UFRJ, $273 \mathrm{p}$.

[23] SABIR, B. B., WILD, S., BAI, J. Metakaolim and calcined clays as pozzolanas for concrete: a review. Cement and Concrete Composites, v.23, n.6, 2001, pp. 441-454.

[24] TAYLOR, H. F. W. Cement chemistry, $2^{\text {nd }}$ ed. London: Thomas Telford, 1997, $459 \mathrm{p}$.

[25] CYR, M., LAWRENCE, P., RINGOT, E. Efficiency of mineral admixtures in mortars: Quantification physical and chemical effects of fine admixtures in relation with compressive strength, Cement and Concrete Research, v. 36, n.2, 2006, pp. 264-277.

[26] GHRICI, M., KENAI, S., SAID-MANSOUR, $M$. Mechanical properties and durability of mortars and concrete containing natural pozzolana and limestone blended cements. Cement and Concrete Composites, v. 29, n.7, 2007, pp. 542-549.

[27] ANTONI, M., ROSSEN, J., MARTINERA, F., SCRIVENER, K. Cement substitution by a combination of metakaolin and limestone, Cement and Concrete Research, v. 42, n.12, 2012, pp. 1579-1589.

[28] DE LARRARD, F. Concrete mixture proportioning: a scientific approach. London: E \& FN Spon, 1999.

[29] ASSOCIAÇÃO BRASILEIRA DE NORMAS TÉCNICAS. Cimento Portland destinado à cimentação de poços petrolíferos - Requisitos e métodos de ensaios: NBR 9831. Rio de Janeiro, 2006.

[30] CORDEIRO, G. C., DÉSIR, J. M. Potencial de argila caulinítica de Campos dos Goytacazes-RJ na produção de pozolana para concreto de alta resistência. Cerâmica, v.56, n.337, 2010, pp. 71-76.

[31] KANTRO, D. L. Influence of water-reducing admixtures on properties of cement paste - A miniature slump test. Cement, Concrete and Aggregates, v.2, n.2, 1980, pp. 95-102.

[32] CHAIPANICH, A., NOCHAIYA T. Thermal analysis and microstructure of Portland cement-fly ash-silica fume pastes. Journal of Thermal Analysis and Calorimetry, v.99, n.2, 2010, pp. 487-493.

[33] DWECK, J., CUNHA, A. L. C., PINTO, C. A., GONÇALVES, J. P., BÜCHLER, P. M. Thermogravimetry on calcined mass basis - Hydrated cement phases and pozzolanic activity quantitative analysis. Journal of Thermal Analysis and Calorimetry, v.97, n.1, 2009, pp. 85-89.

[34] CORDEIRO, G. C., TOLEDO FILHO, R. D., TAVARES, L. M., FAIRBAIRN, E. M. R. Ultrafine grinding of sugar cane bagasse ash for application as pozzolanic admixture in concrete. Cement and Concrete Research, v.39, n.2, 2009, pp. 110-115. 